\title{
PREDICTING BOTTOM CURRENT DEPOSITION AND EROSION ON THE OCEAN FLOOR
}

\author{
Daan Beelen*, Lesli J. Wood
}

SAnD Consortium, Colorado School of Mines, Department of Geology and Geological Engineering, 1500 Illinois Street, Golden, CO,USA, dbeelen@mines.edu,lwood@mines.edu

*Correspondence (daanbeelengeologist@gmail.com)

Twitter: @daanosaurus_rex

This manuscript is a preprint published on July 28th, 2021 in the preprint server EarthArXiv. It has also been submitted for publication in Basin Research. Although the contents of this preprint are true and complete according to the authors; future versions may have slightly different wording or figures. Please contact the lead author Daan Beelen (dbeelen@mines.edu) if you have any questions or comments about this preprinted manuscript.

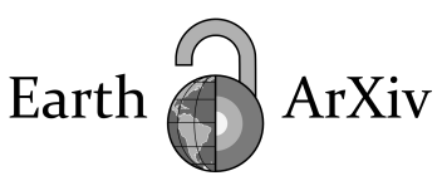




\begin{abstract}
Three types of oceanographic data are integrated in this study to predict thermohaline geostrophic bottom current deposition and erosion on the ocean floor. These data types are, 1) high-resolution bathymetry, 2) numerical model data of bottom current shear stress and 3) model data of the distribution and amount of sediment on the ocean floor. Intervals of thermohaline geostrophic bottom current deposition and erosion can be quantified from this information, which are then be extrapolated across the ocean floor in $4.5 \times 9.3 \mathrm{~km}$ grid-size resolution. The results of this analysis are displayed on a map that shows the distribution of zones of bottom current erosion and deposition. This map is then cross-referenced for accuracy using documented examples of mapped erosional and depositional bottom current systems, which demonstrates this study's approach has strong predictive capabilities. The model developed herein is used to derive boundaries for depositional bottom current regimes and formulate generalized patterns that contribute to bottom current erosion and deposition, and then discuss the importance of these interpretations for resource extraction and ocean floor mapping.
\end{abstract}




\section{INTRODUCTION}

In the field of sedimentology, the deep marine realm remains the largest and least understood depositional environment on Earth. Despite this, the ocean floor experiences a limited range of depositional processes, which are dominated by thermohaline circulation; a continuous overturning of vast water masses, driven by several 'deepwater formation pumps' located near the Earth's poles. Zones of deepwater formation generate relatively dense water through cooling and salinification of ocean surface waters. From these areas of deepwater formation, surface waters sink to the ocean bottom, and then emanate across the entire ocean floor, driving a global conveyer of deep ocean currents. Bottom water masses eventually reach areas of upwelling, which are typically adjacent to steep, active continental margins (Xie and Hsieh 1995). Coastal upwelling brings deep ocean waters back to the surface through a complex series of mostly wind-driven processes, notably Ekman transport (Xie and Hsieh 1995; Jacox et al., 2018). In between deepwater formation and coastal upwelling, the speed and direction of bottom currents is largely controlled by the topography of the seafloor and the location of Earth's continents (Rebesco et al., 2014). Furthermore, the rotation of the Earth leads to a so called 'geostrophic' deflection of bottom currents through the Coriolis Effect. These factors combine to form a continuous pattern of deepwater currents called geostrophic bottom currents, or simply, bottom currents. Bottom currents are decoupled from shallow and middle water masses through kinetic barriers that are defined by rapid temperature, pressure, and salinity changes in the oceanic water column. One such barrier is the thermocline; a well-defined layer of uniquely sharp changes in temperature that typically sits $400-1,000 \mathrm{~m}$ below the ocean surface (Zenk, 2008). The thermocline, like related oceanographic barriers like the salt-content controlled halocline, separate stratified ocean volumes called surface, intermediate, deep, and bottom waters (Stow et. al., 2018; Cheng et al., 2020). All these ocean volumes can have a unique regime of currents that can act on sediments, but the currents that impinge most dominantly on oceanic sediments are bottom currents. Aside from thermohaline circulation, deep tides and abyssal storms are also important processes that affect deep ocean environments, but the relative importance of thermohaline currents with respect to tidal processes and other processes in deep ocean environments remains unclear and is an ongoing research pursuit (Hüneke and Stow, 2008; Rebesco et al., 2014; Stow et al., 2018). Bottom currents tend to be relatively slow (typically $0.01-0.5 \mathrm{~m} / \mathrm{s}$; Stow et al., 2009), yet omnipresent and incessant. They shape the geomorphology of vast portions of the ocean floor by entraining, transporting and depositing material on the abyssal plain (Rebesco et al., 2014). Bottom currents do fluctuate in intensity, but overall, the deep marine realm is relatively predictable and less stochastic than the continental or shallow marine realms, on average having les rapid fluctuations in current intensities. This allows for relatively accurate numerical modelling of the direction and intensity sedimentary processes and shear stresses that act on the ocean floor (Trossman et al., 2016; Thran et al., 2020). Arguably, ocean bottom currents are one of the most important processes in sedimentology, as it dominates the largest depositional environment on Earth (the abyssal plain), has the longest continuous effects (typically longer than several million years) and generates the largest bedforms on Earth (Flood, et al., 1993). Despite this, deposits that have been formed by 
bottom processes are likely the least well understood, because they are hard to reach, and because ancient bottom current deposits identified on land (surface outcrop analogues) are rare, due to their low preservation potential on geological timescales (Stow et al., 1998; Hüneke and Stow, 2008; Rebesco et al., 2014; Beelen et al., 2020).

Table 1. Overview of process environments in the world's oceans (Rich, 1951; Hüneke, H., and Stow, 2008; Rebesco et al., 2014; Stow et al., 2018).

\begin{tabular}{|c|c|c|c|c|}
\hline $\begin{array}{c}\text { Dominant sedimentological process (Rich, } \\
\text { 1951; Hüneke and Stow, 2008; Rebesco et al., } \\
\text { 2014; Stow et al., 2018) }\end{array}$ & $\begin{array}{c}\text { Shallow } \\
\text { marine } \\
\text { tides }\end{array}$ & $\begin{array}{c}\text { Continental } \\
\text { shelf } \\
\text { sediment } \\
\text { gravity flows } \\
\text { gravity flows } \\
\text { and bottom } \\
\text { currents } \\
\text { slope }\end{array}$ & $\begin{array}{c}\text { Continental } \\
\text { currents }\end{array}$ & $\begin{array}{c}\text { Abyssal } \\
\text { plain }\end{array}$ \\
\hline Typical depth & $0-50 \mathrm{~m}$ & $50-200 \mathrm{~m}$ & $200-3,000 \mathrm{~m}$ & $>3,000 \mathrm{~m}$ \\
\hline Depositional energy & High & Low & Medium & Low \\
\hline $\begin{array}{c}\text { Percentage of the ocean floor ) } \\
\text { https://www.britannica.com/science/continental- } \\
\text { shelf) }\end{array}$ & $8 \%$ & $8.5 \%$ & $8 \%$ & $75.5 \%$ \\
\hline $\begin{array}{c}\text { Preservation potential on geologic timescales } \\
\text { Dery high }\end{array}$ & High & Low & Very low \\
\hline
\end{tabular}

\section{Nomenclature}

In recent years, there has been an increase in the research interest on contourites, which are sedimentary deposits formed by bottom currents in deep oceans and seas. The term 'contourites' is synonymous with 'contourite drifts' and was initially defined as: 'Sediment accumulations driven by bottom currents, that trend the contours of ocean bathymetry maps' (Stow and Lovell, 1979). Alternatively: 'sedimentary deposits in the deep sea that are formed by (bathymetric) contour-parallel thermohaline currents' (Heezen and Hollister, 1971). The coast-parallel character of these deposits comes from bottom currents that are deflected by large landmasses and thus trend continental slopes and shelves, where they are called boundary currents. More recently, contourites have been defined as 'Sediment accumulations that have been emplaced or significantly affected by deep marine bottom currents' (Rebesco et al., 2014). 'Bottom currents' or, 'deep ocean currents' in turn, are described as currents that exist in 'deep-waters' which is often considered to be below the thermocline (400 - 1,000 m; Stow et. al., 2018). As explained previously, most currents at these depths are thermohaline-driven geostrophic currents, but winds (e.g. internal waves and 
abyssal storms), and more importantly, deep (internal) tides, also play a role, as well as Rossby waves (Garrett and Munk, 1979; Chelton and Schlax, 1996) and other processes like gateway outflow water (e.g. Toucanne et al., 2007). The impact and relative importance of abyssal storms, internal waves and tides is poorly understood and may be negligible in most settings (Rebesco et al., 2008; Faugères and Mulder, 2011). In any case, geostrophic currents are believed to be the dominant process at abyssal (>3,000 $\mathrm{m}$ water) depths (Stow et al., 2018).

In addition to continuous processes, deep marine deposits are typically formed under the combined action of bottom currents and sediment/mixed-fluid gravity flows, which include turbidity currents and hyperpycnal flows (Fig. 1; Mulder et al., 2003). The combination of these processes can generate deposits ranging from so-called moat and drifts (Rebesco and Stow, 2001), to plastered drift and sheeted drifts (Rebesco and Stow, 2001; Faugères et al., 1999). These features are collectively referred to as 'contourites'. However, in this study we make the distinction between such systems and 'abyssal dunefields', the latter of which are driven entirely by geostrophic bottom currents (Fig. 1). Such types are sometimes called mudwave systems (e.g. Flood et al., 1999) and can accumulate sediment over large tracts of the abyssal plain (sometimes $>1,000,000 \mathrm{~km}^{2}$ ). Abyssal dunefields geomorphologically resemble subaerial ergs and aeolian systems, as they are comprised of various types of migrating dunes like barchan, transverse and linear dunes (e.g. Lonsdale and Malfait, 1974). Abyssal dunes are dunes located in deep water and are roughly synonymous to 'sediment waves' with the exception that the term sediment waves also encompasses cyclic steps, which are supercritical bedforms that migrate against the current (Slootman and Cartigny, 2020). Abyssal dunes can be coarse grained (sandy) but are mainly fine grained (silty or clayey; Fig. 1; Stow et al., 1998). 


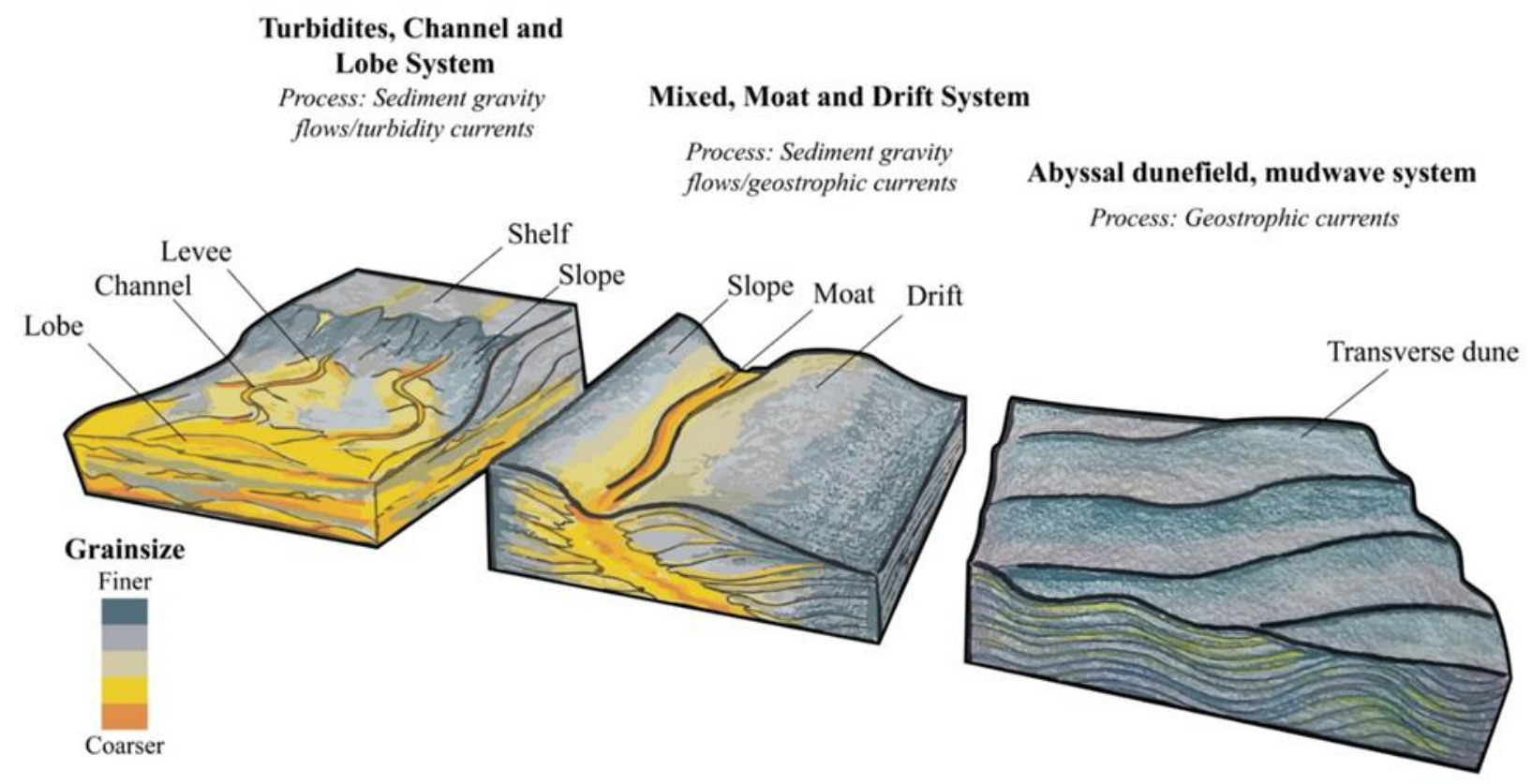

Figure 1. Schematic representation of three deep ocean sedimentary depositional systems. Left: a gravitationally driven system comprised of turbidity current driven channels and lobes. Middle: a system driven by both gravitational systems, which feed sandy material to the 'moat', and geostrophic bottom currents which redistribute a fine grained fraction into an adjacent 'drift'. This system is called a moat and drift system and is a type of contourite. Right: An abyssal dunefield (sometimes called mudwave system). This system is comprised of transverse dunes that originate and move entirely under the action of geostrophic bottom currents.

Over the past few decades, a growing amount of high-resolution multibeam sonar has become publicly available and has elucidated the geomorphologies in various regions of the ocean floor (Marks, and Smith, 2006). This imagery shows that the omnipresent geostrophic bottom currents generate a wide range of features, that can be depositional (e.g. contourites or abyssal dunefields) or erosional (e.g. furrows; Heezen, 1959; Hollister and Heezen, 1972). These globally georeferenced data can thus be used to map the dispersal of such geomorphologies across the ocean floor. This study uses these data to map abyssal plain geomorphologic features and use them to quantify the controls on deep ocean bottom current deposition and erosion (Fig 2). 

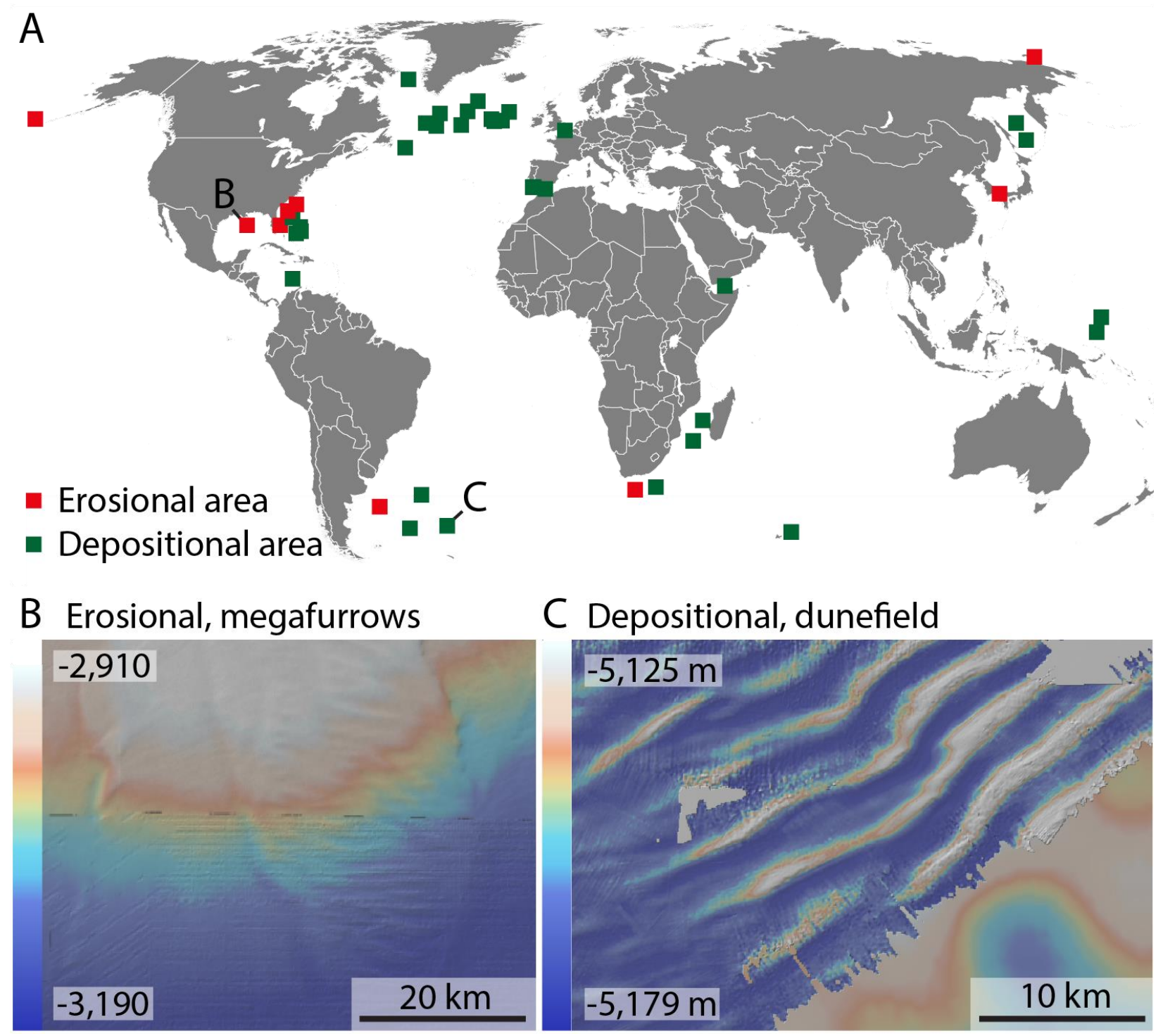

Figure 2. A: World map showing locations examples of locations with visible zones of deposition (green squares) and zones of erosion (red squares). B.. Erosion is visible as furrows. C: Deposition is visible through the presence of abyssal dunefields or contourites on high-resolution bathymetry.

\section{Parameters influencing bottom current deposition and erosion}

Existing models of bottom current dispersal can be resolved in high-resolution, for example by the eddy-resolving HYbrid Coordinate Ocean model (HYCOM; Chassagne et al., 2007). As bottom currents move across the ocean floor, they exert a shear stress on deep ocean sediments. This stress is termed bottom drag in the field of oceanography, but is more commonly referred to as bed shear stress or simply, shear stress in the field of sedimentology. In this study, we compromise and refer to this as: bottom shear stress. Bottom shear stress is controlled by the speed of geostrophic bottom 
currents, as well as the topography of the sea floor, and can be linked to the entrainment, transportation, and deposition of sediments (Trossman et al., 2016; Thran et al., 2018). Previous works have shown that the amount of shear stress on the ocean floor can be linked directly to the dispersal of mapped bedforms on the ocean floor. Such maps have been published in a variety of journal papers or in compilations such as the contourite atlas of Rebesco et al. (2014) or Claus et al. (2017). Such a methodology has greatly helped oceanographers and deep water sedimentologists to determine where accumulations of abyssal bedforms are distributed (Thran et al., 2018). However, a second crucial parameter is missing from existing methodologies that attempt to resolve the dispersal of deep ocean bedforms, which is the distribution of deep ocean sedimentation.

Deep ocean sedimentation occurs by means of two processes 1) settling of authigenic sediments that form in the water column, and 2) the delivery of detrital sediments from continental and shallow marine regions, through gravitational processes. Both of these processes contribute to the total thickness of ocean floor sediments, which have been measured through deep ocean core and reflection seismic data and have been published in Straume et al. (2019). This study therefore combined two parameters that are fundamental to the dispersal of deep ocean sediment deposits: bottom shear stress and sedimentation availability, to improve upon existing models for the distribution of deep marine sediment accumulations. Furthermore, the combined sediment dispersal and bottom drag data allow for the mapping of both erosional and depositional zones on the ocean floor, thereby complementing existing models which focus on deposition alone (Thran et al., 2016).

\section{METHODS}

Areas of deep ocean deposition are identified on high-resolution bathymetry data that are accessed through GeoMappApp and Google Earth (Marks and Smith, 2006). Zones of deposition are identified based on the presence of abyssal dunes, contourites, or any other type of active deep ocean sediment deposit that was emplaced by bottom currents (Fig. 2; Viana et al., 1998). These areas are researched in the literature to determine if they are currently active or relict, like for example the Hatteras dunefield which became inactive during the Miocene according to Locker and Laine (1992). Similarly to depositional areas, areas of erosion are identified on bathymetric data by localizing furrows or megafurrows (e.g. Niedoroda et al., 2003).

\section{Sediment supply}

Although sediment is deposited across all the world's oceans, many places, such as near mid-ocean ridges have too little sediment accumulation to develop widespread bottom current deposits, despite bottom shear stress being sufficient in some of these areas. To understand where these low sediment-supply regions exist, the total amount of sea-floor sediment accumulated is used as proxy for the amount of sediment supply. The amount of total ocean floor sediment has been accurately determined for the entire ocean floor in a series of detailed sediment thickness maps. These are constructed from interpolating sediment column thicknesses obtained from seismic data and ocean drilling and are published as the GlobSed project (Straume et al., 2019). Although the amount of 
total seafloor sediment thickness is not the same as the amount of sediment supply, it is a strong indicator for the distribution of the magnitude of sediment deposition. For instance, mid ocean ridges and submarine platforms that sit well above the abyssal plain and are at a far distance from the shore, gain much less sediment from the slope and coast than most regions of the ayssal plain (Straume et al., 2019). Mid-ocean ridges and isolated submarine platforms thus have low sediment supply, which is reflected in the GlobSed ocean thickness data as zones of sparce sediment accumulation (Straume et al., 2019).

\section{Quantifying bottom shear stress}

Like the sediment supply, the amount of bottom shear stress exerted by bottom currents onto the ocean floor also varies in space (Trossman et al., 2016). For example, high rugosity and large obstacles like continental shelves or seamounts are conducive to the local development of high bottom shear stresses, by presenting obstruction for current to impinge upon or by locally constricting current flow (Trossman et al., 2016). The spatial distribution and magnitude of ocean bottom shear stress can be modelled using an eddy-resolving numerical ocean model, which incorporates thermohaline conveyer current volumes and velocities, deep tidal activity, sea floor topography, and rugosity and bottom current confinement and divergence due to coastline configurations. In this study, the HYbrid Coordinate Ocean Model (HYCOM) is used (Chassignet et al., 2009). This model allows inference of values for ocean bottom shear stress on a global ocean scale, in high-resolution, with an average grid size of $4.5 \times 9.3 \mathrm{~km}$. The model values used in this study are from (Trossman et al., 2016); who incorporate internal wave drag to model bottom stress in high accuracy. Bottom stress data used in this study represent present, yearly (seasonally) averaged values following a 32-year 'spin-up' or equilibration period of the HYCOM model (Trossman et al., 2016).

\section{Developing the bottom current deposition and erosion map}

A sediment thickness versus bottom shear stress matrix is populated with depositional locations that have been determined to be currently active on bathymetry surveys (Fig. 2A, B). After adding locations with bottom current deposition, the matrix is populated with actively erosional locations, visualized through the presence of furrows on bathymetry surveys (Fig. 2A, C). The sediment thickness versus bottom shear stress matrix reflects empirically constrained regimes of bottom current deposition and erosion (Fig. 3). These regimes for bottom current deposition and erosion are then quantified, using the global models of bottom shear stress and ocean sediment availability (Chassignet et al., 2009; Straume et al., 2019; Fig. 3C). Depositional and erosional locations are plotted on the sediment thickness versus bottom shear stress matrix, with shear stress on the $\mathrm{x}$-axis and sediment thickness on the y-axis (Fig. 3A). In total, 60 bathymetric areas with recognizable deposition or erosion are listed on the sediment thickness versus bottom shear stress matrix, showing that deposition consistently occurs within an interval between 0.00117 and $0.04 \mathrm{~N} / \mathrm{m}^{2}$ of bottom shear stress, and a sediment thickness between 534 and 4,300 $\mathrm{m}$. The zone of erosion lies

in $>0.04 \mathrm{~N} / \mathrm{m}^{2}$ bottom shear stress. The rest of the shear stress vs. sediment thickness matrix lies in the regime of stasis (Fig. 3B). Quantified regimes of bottom current deposition and erosion are 
then extrapolated across the ocean floor to form a global map of bottom current deposition and erosion. The resulting depositional and erosional areas are visualized on equirectangular map projections, to form a global map that displays areas of sediment deposition, erosion and stasis (Figs. 4, 5C; Supplementary Information). The resulting map is then cross referenced with existing areas that have depositional and erosional areas mapped in high resolution (Fig. 6; Rebesco et al 2014; Claus et al., 2017). This shows that there is a strong spatial correlation between our procedurally modelled zones of deposition and mapped contourites and abyssal deposits. These results therefore predict the presence and extent of contourite deposits and erosional zones across sea floor landscapes, even in locations where high-resolution sonar data is lacking. 
A Sediment supply versus bottom shear stress matrices

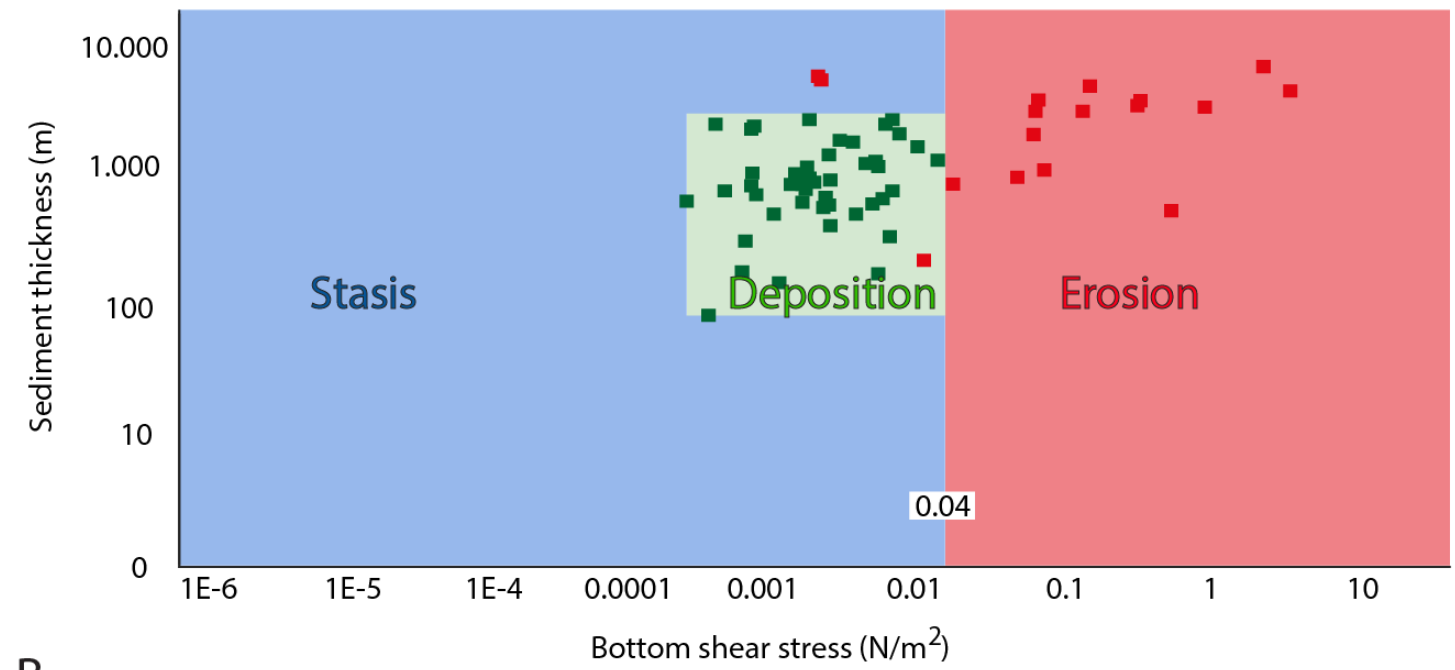

B

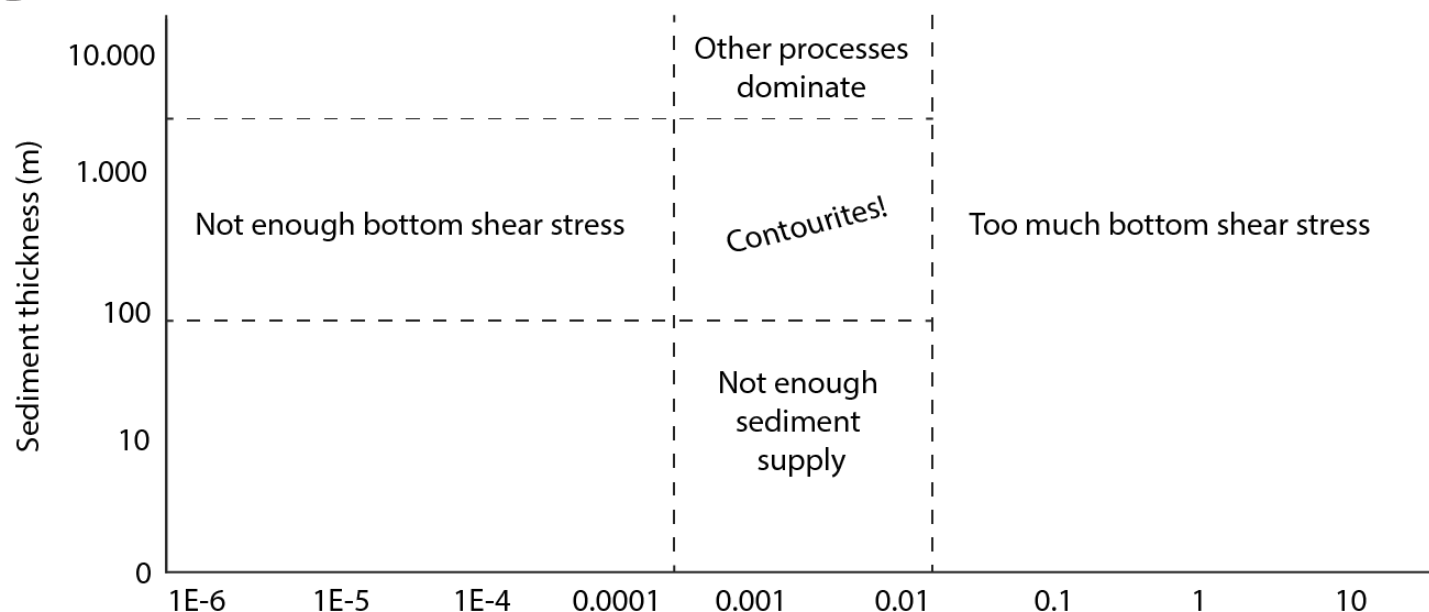

C
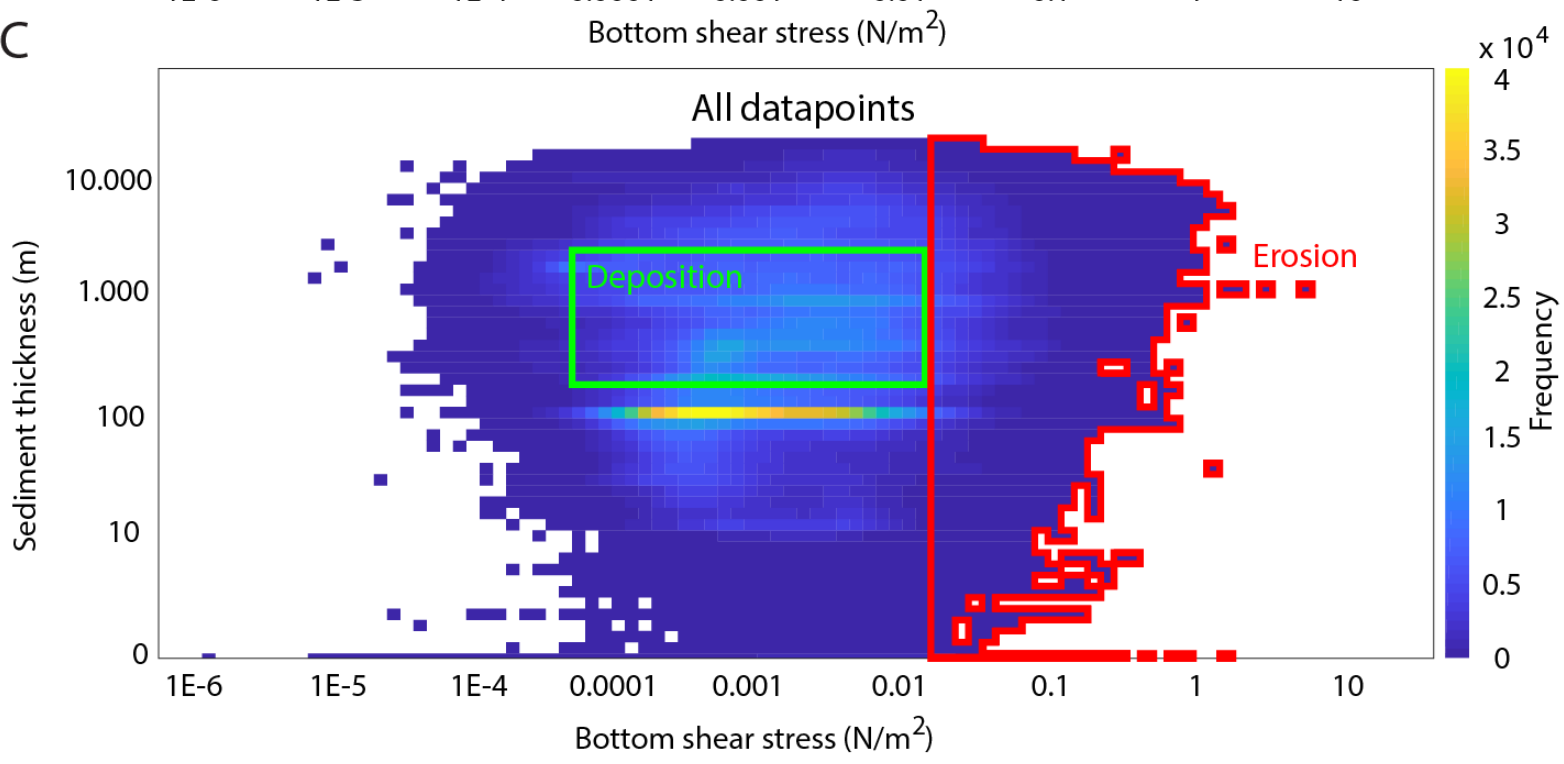
Figure 3. Three matrices showing intervals of geostrophic deposition, erosion and neither (stasis). A: Schematic matrix of log bottom shear stress on the X-axis and log Sediment thickness on the $Y$ axis. The green box denotes the regime associated with the geostrophic deposition of sediments. The red box show the regime associated with erosion. The rest is associated with stasis. Points on the matrix correspond to locations on the ocean floor that have been empirically linked to deposition or erosion by analyzing high-resolution bathymetry data, B: Same matrix as A, with schematic representations of the various depositional and erosional regimes. $C$ : Matrix showing all datapoints plotted as a density graph. This shows that the most widespread interval is near 100 meters of sediment thickness and $0.001 \mathrm{~N} / \mathrm{m}^{2}$ of bottom shear stress. Green box shows depositional regime and red interval shows erosional regime.

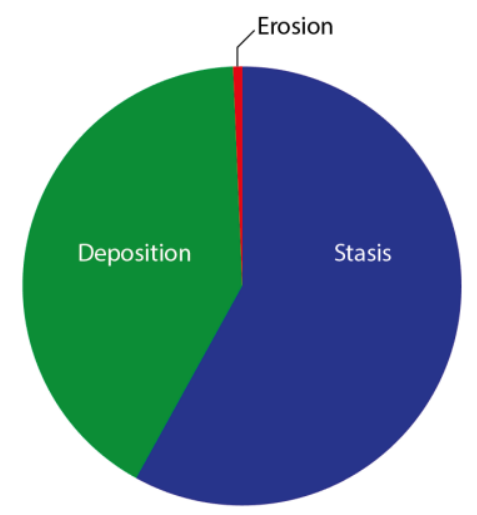

Figure 4. Pie diagram showing the percentage of the ocean floor covered by bottom current stasis (58\%), deposition $(41 \%)$ and erosion (1\%).

\section{RESULTS}

The shear stress and sediment thickness matrix was populated by 60 locations scattered across the ocean floor (Fig. 3). Locations are at depths ranging from $-440 \mathrm{~m}$ to $-5,190 \mathrm{~m}$ with an average of $-3,352 \mathrm{~m}$, which is abyssal water depth. The map that resulted from the extrapolation of quantified erosional and depositional regimes, shows regions of bottom current deposition (green) erosion (red) and stasis (blue). According to our results, around $75.5 \%$ of the Earth is covered in oceans and seas, from this fraction, $58.0 \%$ is in stasis, $41.3 \%$ is depositional, and $0.7 \%$ is erosional (Fig. 4). These percentages correspond to $22,347,627,551 \mathrm{~km}^{2}$ of stasis, $15,904,290,699 \mathrm{~km}^{2}$ of deposition and $260,631,750 \mathrm{~km}^{2}$ of erosion. Most zones of sediment deposition are nearby continental slopes, as these regions capture abundant sediment from relatively nearby continents, and also because these areas have significant topography, which can amplify bottom shear stress. 
Aside from these areas, there are extensive regions of very deep ocean (> 4,500 $\mathrm{m}$ water depth) that have abundant bottom-current driven deposition and dunefields. Examples are the Argentine Basin, the northern Atlantic Ocean as well as areas in the Indian and Southern Oceans. Confined areas and sea straits like the Bering Strait and the Drake Passage are mostly undergoing erosion, while most of the abyssal plain nearby the mid-ocean ridges is experiencing stasis (Fig. 5C; Supplementary Information).

\section{INTERPRETATIONS}

\section{Depositional zones}

Major zones of deposition are in the northern Atlantic Ocean (e.g. Gloria, Eirik, Björnsson, Gardar and Feni drifts, McCave and Tucholke, 1986; Flood et al., 1979), the Argentine Basin (Zapiola Drift), the Mozambique Channel and the Agulhas depositional systems (e.g. Breitzke et al., 2017), the Australian and Indonesian continental shelves, the Bering Sea, and areas of the Southern Ocean

(e.g. Cosmonaut Drift and Larsen Sea Drift, Rebesco et al., 2014). In general, depositional areas tend to occur on continental slopes, where abundant sediment is collected from the land, and significant topography is present to amplify shear stresses exerted by bottom currents and boundary currents. Examples of these areas are the Antarctic circumpolar currents, the north Atlantic boundary current and the Agulhas boundary current. Another type of area with abundant bottom current deposition are abyssal regions with significant intermediate-to-bottom water downwelling such as barotropic vortices, which occur irrespective of pressure and temperature gradients. In these regions, sediment is trapped, and vigorous bottom currents can develop this sediment into extensive dunefields like the Zapiola abyssal dunefield offshore Argentina (Volkov et al., 2009). Additionally, deposition can occur in abyssal regions with abundant and large-scale topography like the Kerguelen Plateau and the Zealandia submarine continent (Fig. 5C). In these areas, topographic obstacles like seamounts can locally amplify bottom shear stresses, causing bottom current deposits to form onto or adjacent to these features. 
A

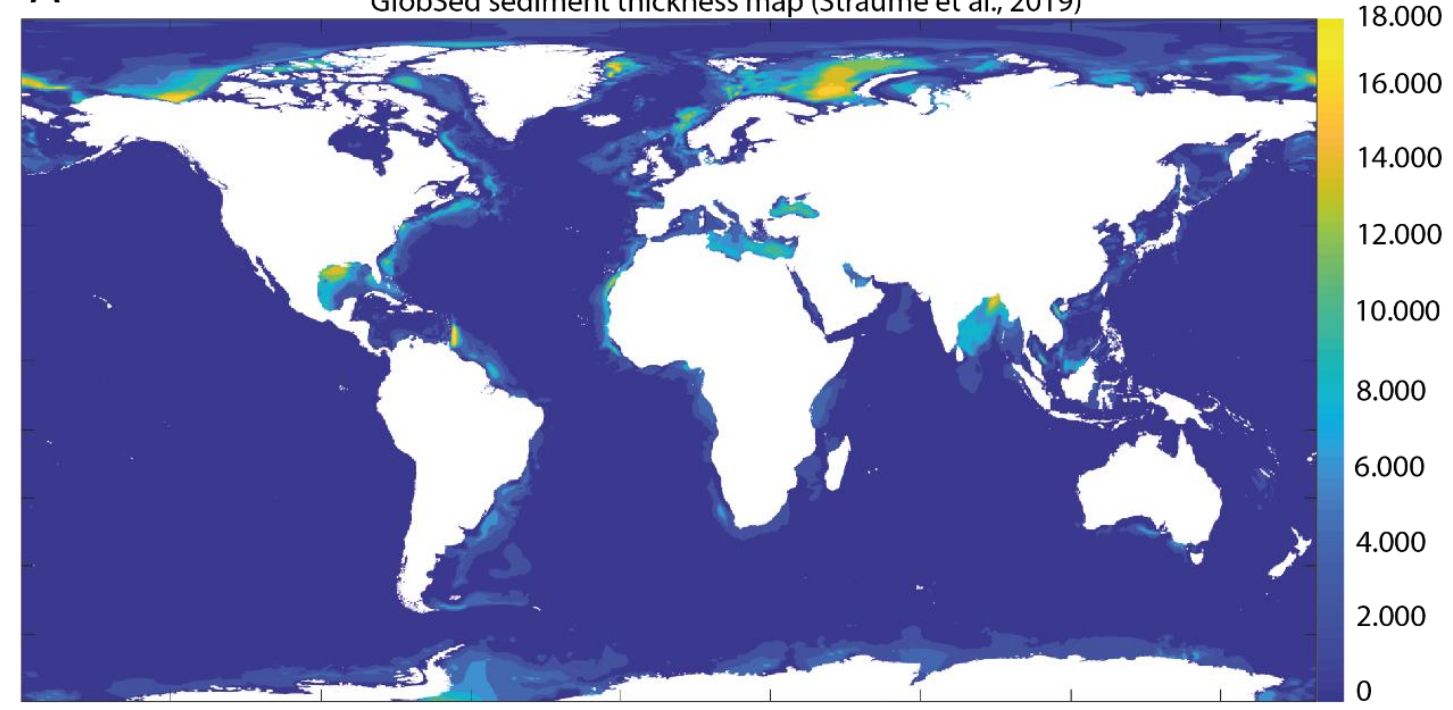

B

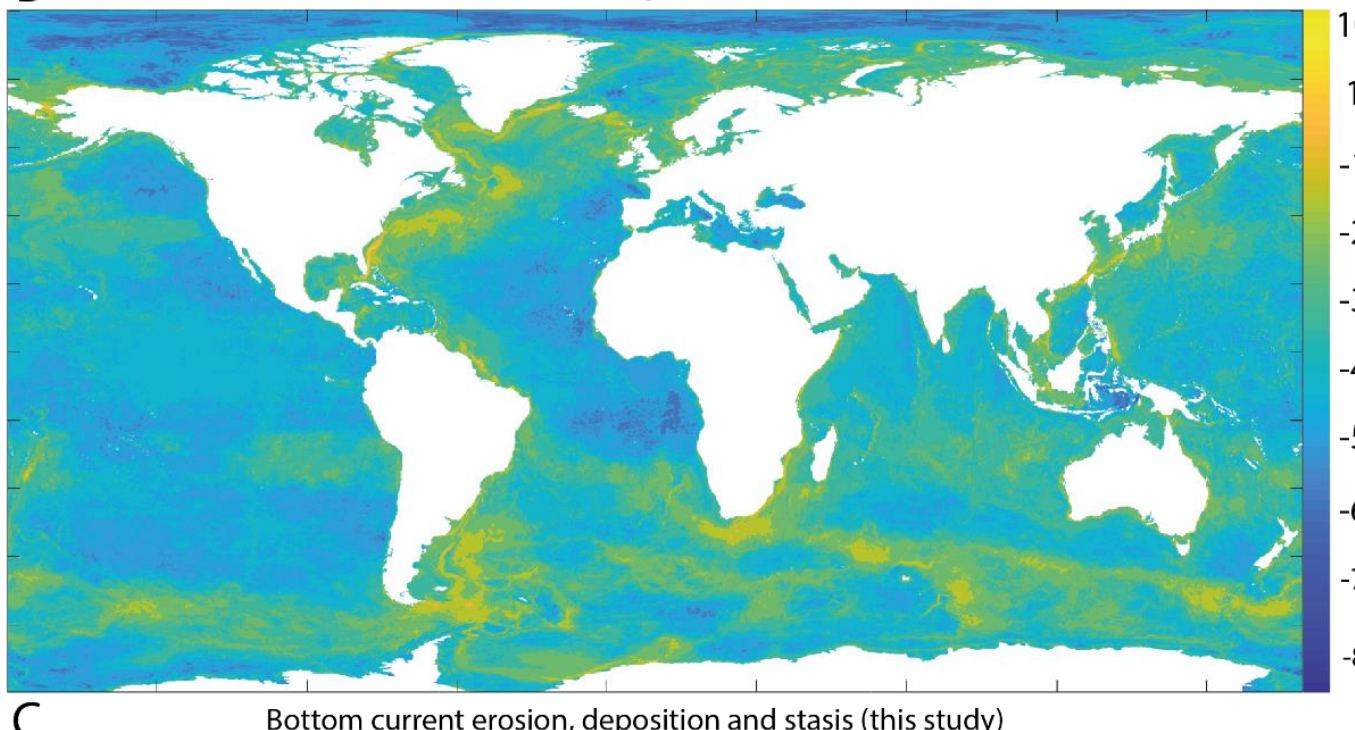

C

Bottom current erosion, deposition and stasis (this study)

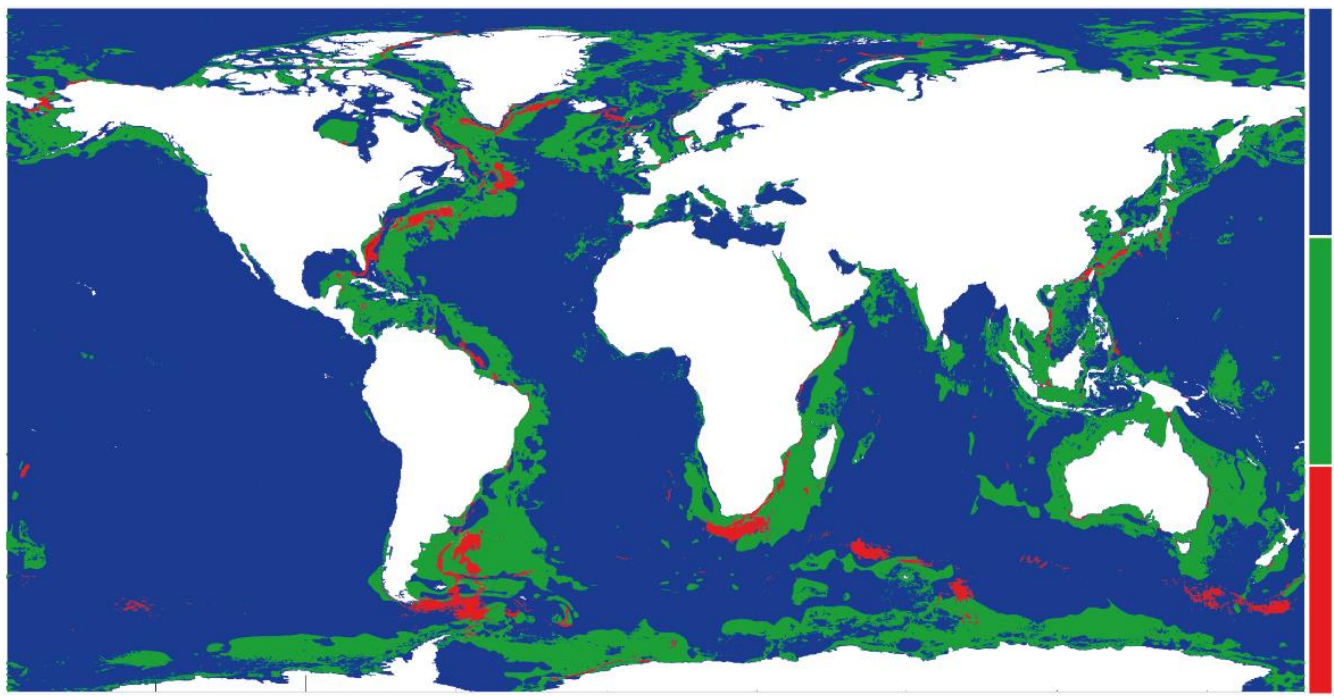

Stasis

Deposition

Erosion 
Figure 5. Maps showing sediment thickness (A), bottom shear stress (B) and the dispersal of bottom current erosion and deposition $(C)$. A: GlobSed sediment thickness map by Straume et al. (2019). B: Bottom shear stress across the world's oceans modelled by HYCOM (Chassignet et al., 2009; Trossman et al., 2016). C: Map showing the modelled dispersal of bottom current erosion and deposition. This map was constructed by extrapolating regimes of bottom current erosion and deposition onto a world map with the same equilateral projection as the maps shown in $A$ and $B$.

Table 2. Three settings that are associated with abundant deposition from bottom currents.

\begin{tabular}{|c|c|c|}
\hline Deposition & Deposition Example & Process \\
\hline Continental slopes & $\begin{array}{c}\text { Santos Drift (Duarte and } \\
\text { Viana, 2007), }\end{array}$ & $\begin{array}{c}\text { Geostrophic bottom current amplification due to } \\
\text { topography: boundary currents. }\end{array}$ \\
\hline $\begin{array}{c}\text { Deep ocean } \\
\text { barotropic vortices }\end{array}$ & $\begin{array}{c}\text { Zapiola drift (Klaus and } \\
\text { Ledbetter 1988; Flood and } \\
\text { Shor, 1988) }\end{array}$ & Barotropic vortices. \\
\hline $\begin{array}{l}\text { Regions adjacent to } \\
\text { mounds, submarine } \\
\text { platforms and other } \\
\text { obstructions on the } \\
\text { seafloor }\end{array}$ & $\begin{array}{c}\text { Rockall sheeted drift } \\
\text { (Masson et al., 2002). }\end{array}$ & Geostrophic bottom current amplification due to \\
topography.
\end{tabular}

\section{Erosional zones}

Major zones of bottom current erosion are off the east coast of the United States, such as the area around the Blake Plateau, located offshore east of Florida. This area has the most powerful bottom currents in the world: the Florida Current or, Southern Gulf Stream Boundary Current (Spall, 1996), which exerts up to $6.4 \mathrm{~N} / \mathrm{m}^{2}$ of shear stress onto the seafloor (Trossman et al., 2016). This system continuously removes and redistributes sediment, thereby developing an enormous depositional system called the Blake Ridge, which occurs in association with a large erosional feature (Fig, 5C). Other major erosional areas are: west of the Zapiola Drift, trending along the Argentinian Continental Shelf, the Agulhas Boundary current, the Kerguelen Plateau and south of the New Zealand Plateau and the Bering Strait. Powerful, erosional boundary currents are easy to identify on bathymetric data, as they tend to smooth-out continental slopes due to continuous erosion, whereas non-erosional slopes tend to be scarred by numerous scours that formed by gravity processes like turbidity currents, giving them a rugose texture (Fig. 6).

Zones of deep water erosion are also common in sea straits, where geostrophic or deep tidal currents are confined and amplified. Some examples are the Mozambique Strait, Bering Strait, or 
the Gulf of Cadiz (Figs. 8). In the latter, Mediterranean Outflow Water generates bottom currents that are known to erode the seafloor, and form depositional contourites (Hernández-Molina et al., 2016). According to the model presented herein, the English Channel has both areas of deposition and erosion, but appears to be dominantly erosional in its central, narrowest region where amplified tides are known to develop furrows (Flood, 1981).

Smooth shelf, high bottom current shear stress

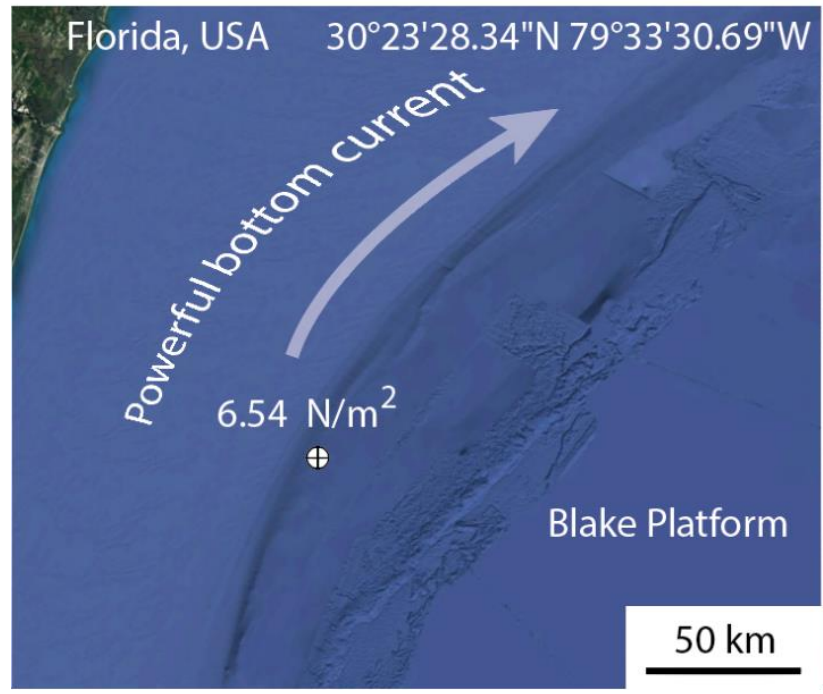

Rugose shelf, low bottom current shear stress

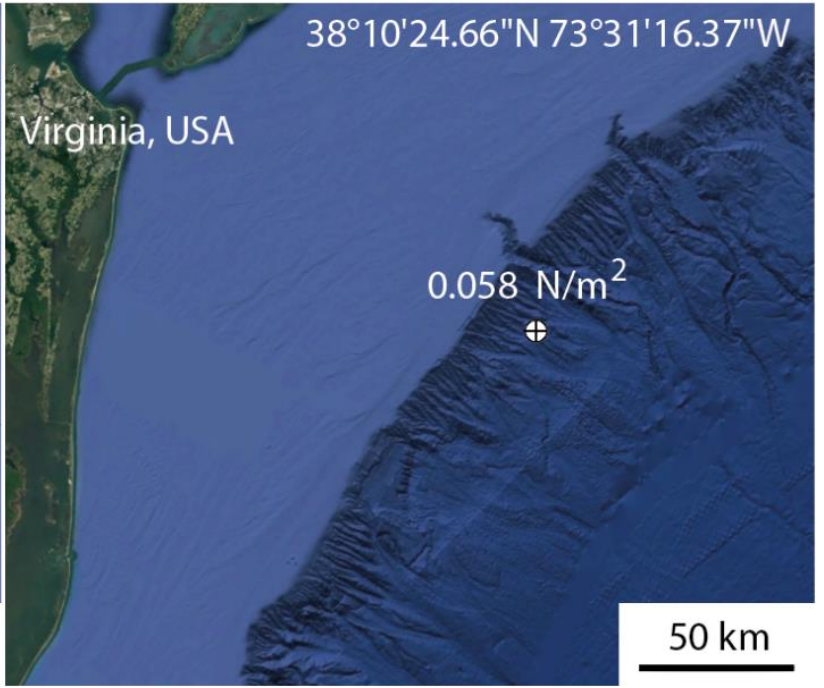

Figure 6. Bathymetry data of two near-adjacently located continental shelf and slope systems off the East Coast of the United States. A: The continental slope adjacent to the Blake Plateau shows a smooth texture. This region is smoothed out by erosion due to high shear stress bottom currents $\left(6.54 \mathrm{~N} / \mathrm{m}^{2}\right)$. B: Continental slope $\sim 1,000 \mathrm{~km}$ north of $(A)$ along the same margin showing an abundance of slope incisions, some impinging on the shelf. This region has low bottom shear stress and turbidity currents develop scars on this slope which remain intact due to lack of erosional bottom currents. 


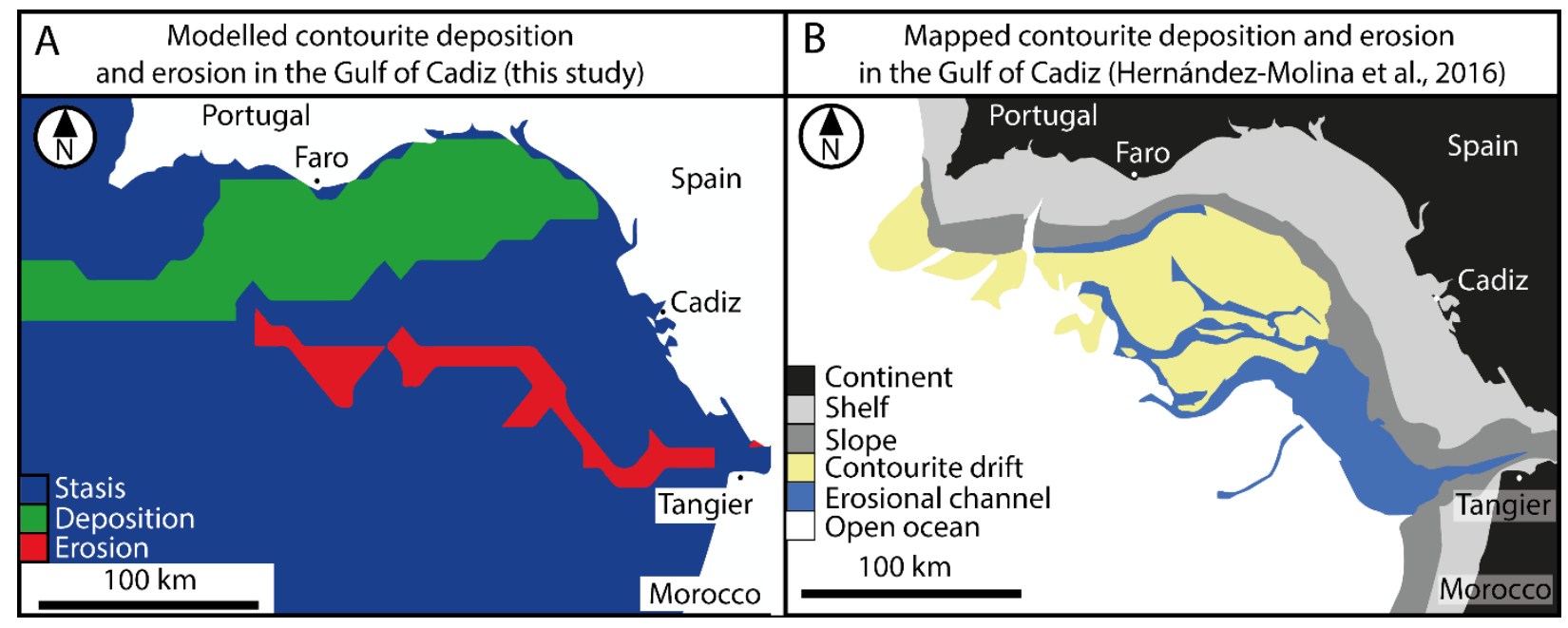

Figure 7. A: Gulf of Cadiz Mediterranean Outflow Water depositional and erosional system, simulated mapping from this study: Blue Stasis: Green: Deposition, Red: Erosion. White: continent. B: The same system mapped in high-resolution from ocean drill core, seismic and bathymetry data (Hernandez-Molina et al., 2016). Blue =erosional moat, Yellow = depositional drift, Dark gray = continental slope, Light Gray $=$ continental shelf, Black $=$ continent .

Table 3. Two settings that are associated with abundant erosion from bottom currents.

\begin{tabular}{|c|c|c|}
\hline Erosion & Erosion Example & Process \\
\hline Sea straits & Bering strait & $\begin{array}{c}\text { Tidal amplification, } \\
\text { confinement of bottom } \\
\text { currents }\end{array}$ \\
\hline $\begin{array}{l}\text { Continental slopes } \\
\text { affected by strong } \\
\text { boundary currents }\end{array}$ & Agulhas current, Gulf Stream east of \\
& $\begin{array}{c}\text { Florida. } \\
\text { Boundary currents }\end{array}$ \\
\hline
\end{tabular}

\section{Stasis}

Stasis is common in regions that are very far from continents where no terrestrially-derived or reworked sediments are available, such as over mid-ocean ridges (Fig. 5C). Areas of deep ocean upwelling have limited amounts of shear stress exerted by bottom currents, and therefore have limited to no contourite and abyssal dunefield deposition, even when there is abundant sediment supply from nearby continental areas. Areas of significant deepwater formation, such as north of 
Iceland or the Weddell Sea near Antarctica have marked zones of stasis, due to a lack of bottom currents passing across the ocean floor in these regions. Instead, water masses move vertically down here, which according to the HYCOM model coincides with a limited amount of bottom shear stress on the ocean floor (Chassignet et al., 2009; Trossman et al., 2016). Some continental shelves can have stasis, such as off the east coast of the United states, as there is limited thermohaline bottom current activity here (Fig. 5B). This lack of bottom current activity on continental shelves may occur because deeper thermohaline bottom currents remain at the abyssal plain, below or on the toe of the continental slope, and tend to not 'climb' up to shallower continental shelves (Fig. 5B; Rebesco et al., 2014). Note that under many circumstances, continental shelves can have enough shear stress to develop deposits, but this shear stress can be from to deep tides that are sometimes amplified near the coast or on the shelf (Davis and Dalrymple, 2011; Rebesco et al., 2014). The amount of tidal shear stress on continental shelves is therefore contingent on the depth of the shelf and the amount of tidal energy in that area. The amount of tidal energy in turn, is mostly controlled by the shelf's relative position to the nearest amphidromic point and the local coastline shape and orientation (Davis and Dalrymple, 2011). Deep, partially or completely enclosed basins like bays and Mediterranean seas are generally bypassed by the global thermohaline bottom current conveyer, leading to very few thermohalinedriven deep currents to exert bottom shear stress in these areas, leading to stasis in these areas. A notable exception is the Mediterranean Outflow Water, which is not driven by thermohaline circulation but by evaporation differentials between the Mediterranean Sea and the Atlantic Ocean (Toucanne et al., 2007).

Table 4. Five settings that are associated with stasis (neither deposition nor erosion from bottom currents).

\begin{tabular}{|c|c|}
\hline Stasis & Stasis Example \\
\hline Zones of deep water upwelling & West of Africa \\
\hline Zones of deepwater formation & Mediterranean Sea, Bay of Bengal \\
\hline Enclosed Basins & $\begin{array}{c}\text { Offshore the east coast of the United } \\
\text { Some continental shelves }\end{array}$ \\
\hline Mid-ocean ridges & Mid-Atlantic ridge \\
\hline
\end{tabular}


Table 5. Regimes of geostrophic bottom current deposition, erosion and stasis. Regime boundaries are quantified, and an explanation of their nature is provided.

\begin{tabular}{|c|c|c|c|c|}
\hline Boundary & $\begin{array}{l}\text { Upper sediment } \\
\text { thickness boundary } \\
\text { for deposition }\end{array}$ & $\begin{array}{c}\text { Lower sediment } \\
\text { thickness boundary } \\
\text { for deposition }\end{array}$ & $\begin{array}{c}\text { Upper bottom shear } \\
\text { stress boundary for } \\
\text { deposition }\end{array}$ & $\begin{array}{l}\text { Lower bottom } \\
\text { shear stress } \\
\text { boundary for } \\
\text { deposition. }\end{array}$ \\
\hline Value & $-4,454 \mathrm{~m}$ & $-129 m$ & $0.0400 \mathrm{~N} / \mathrm{m}^{2}$ & $0.0117 \mathrm{~N} / \mathrm{m}^{2}$ \\
\hline $\begin{array}{c}\text { Nature of the } \\
\text { boundary }\end{array}$ & $\begin{array}{l}\text { Above this } \\
\text { boundary are } \\
\text { typically shallow } \\
\text { marine areas with } \\
\text { high sediment } \\
\text { supply that are } \\
\text { dominated by } \\
\text { gravitationally } \\
\text { driven processes } \\
\text { that overprint the } \\
\text { relatively weak } \\
\text { bottom currents. }\end{array}$ & $\begin{array}{c}\text { Below this } \\
\text { boundary are areas } \\
\text { that have too low } \\
\text { sediment supply to } \\
\text { develop contourites } \\
\text { or abyssal } \\
\text { bedforms. }\end{array}$ & $\begin{array}{l}\text { Above these values } \\
\text { for shear stress, } \\
\text { dominantly erosion } \\
\text { takes places. }\end{array}$ & $\begin{array}{l}\text { Below this value } \\
\text { there is not } \\
\text { enough bottom } \\
\text { shear stress to } \\
\text { move sediment } \\
\text { into contourites } \\
\text { and abyssal } \\
\text { bedforms. }\end{array}$ \\
\hline
\end{tabular}

\section{DISCUSSION}

\section{Model comparison to mapped systems}

The Gulf of Cadiz contourite system is driven by Mediterranean Outflow Water (Toucanne et al., 2007). It contains erosional channels that were formed by strong bottom currents and adjacent contourite depositional systems (Fig. 7; Hernandez-Molina et al., 2016). Although this is a relatively small system on an oceanic scale, it has received a lot of research attention and is well mapped through abundant collection of sonar and sediment core data. This allows comparison between known features on the ocean floor to procedurally modelled features generated in this study. This comparison shows that the model presented here accurately simulates the dispersal of erosional and depositional zones in this area, such as the erosional moat near the strait of the Gibraltar Strait and the adjacent drift to the north of this feature. This study also correctly predicts a field of stasis towards the south and southwest of the Gulf of Cadiz (Fig. 7).

Another mapped system that was modelled accurately is the Zapiola Drift Abyssal dunefield. This is a vast dunefield containing some bedforms up to $125 \mathrm{~m}$ high, which are some of the largest bedforms on Earth (Volkov et al., 2009). Adjacent to these regions of abyssal deposition are zones of extensive ocean floor erosion. These adjacent process areas are all accurately displayed on the procedurally generated map (Fig. 8B). 


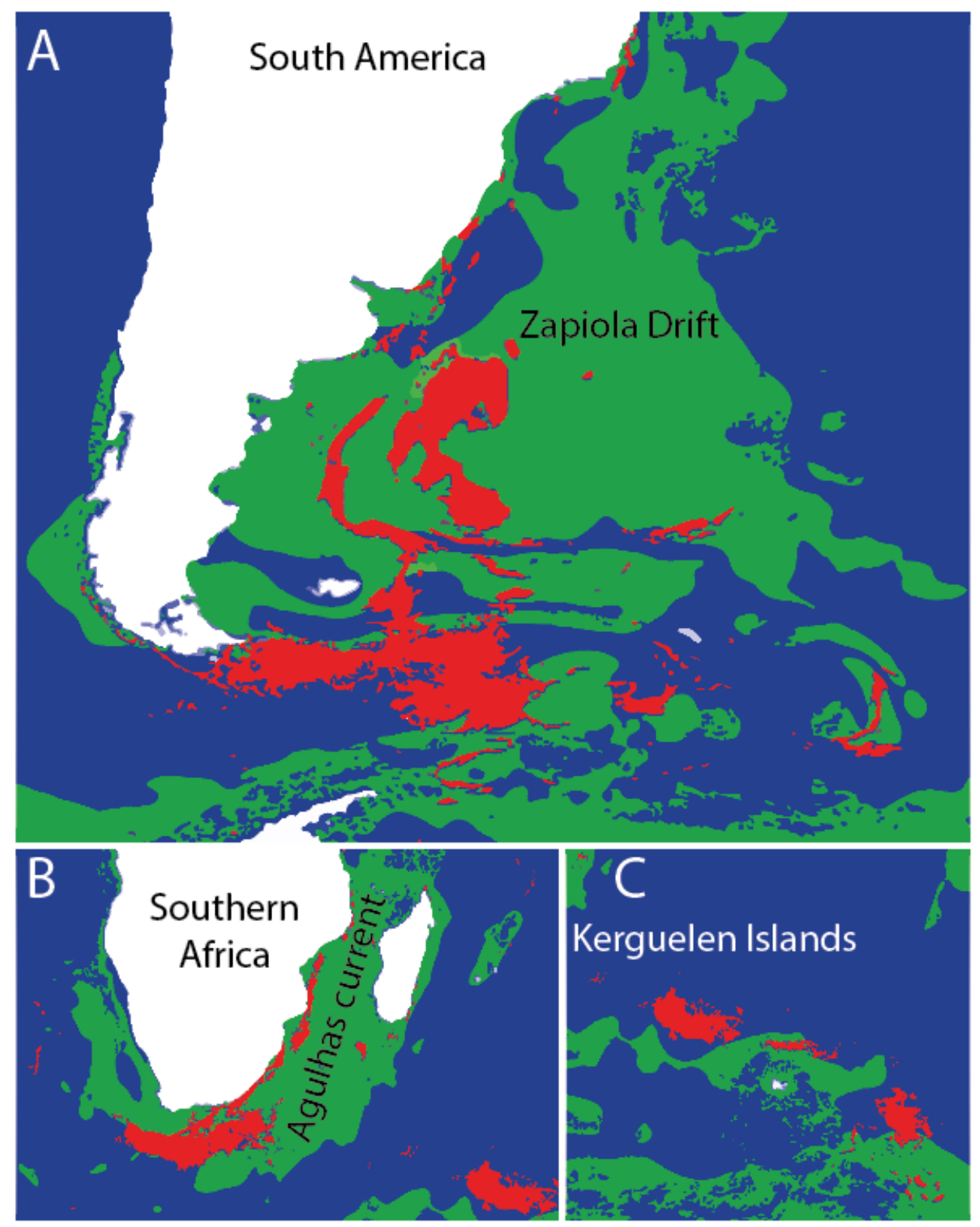

Figure 8. Depositional and erosional bottom current systems in the Southern Hemisphere. A. The enormous Zapiola Drift systems, deposited off the southeast margin of South America, is driven by the Zapiola barotropic vortex or, anticylcone, which traps large amounts of sediments in this region. These sediments develop it into an enormous abyssal field of migrating dunes. B: The Agulhas Current, found off the southern tip of South America, is a powerful geostrophic boundary current that generates a large zone of erosion surrounded both landward and basinward by large zones of deposition. The Mozambique Strait (in between Africa and Madagascar) receives significant open ocean seafloor deposition. . C: A large submarine platform in the Indian Ocean called the Kerguelen Platform has complex systems of bottom current erosion and deposition. 


\section{Unmapped systems}

Aside from these well-known systems, the results of the analysis presented in this study also reveal several regions of deep ocean depositional systems that to our knowledge were hitherto undescribed. Examples are an unnamed dunefield south of India, which, according to our knowledge, may have the largest moving bedforms on Earth. This dunefield, which lies in more than 5,000 $\mathrm{m}$ water depth, contains transverse dunes, some of which are almost 350 meters in height and $10 \mathrm{~km}$ in wavelength (Fig. 9A). Other examples of bottom current depositional systems that are hitherto undescribed in scientific literature are unnamed dunefields northeast of Papua New Guinea and north of Venezuela (Fig. 9).

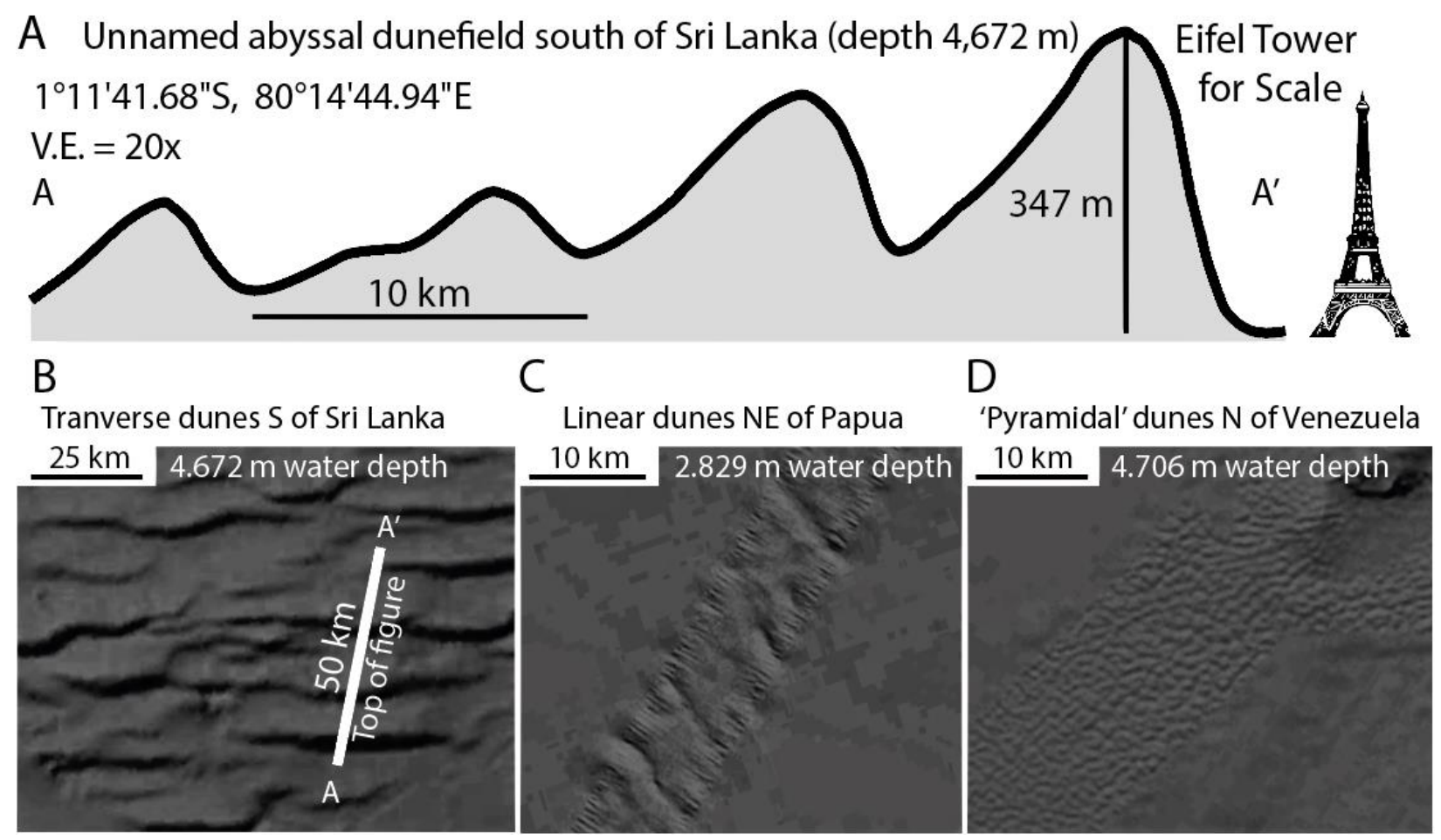

Figure 9. Bathymetric images of three unnamed dunefields illustrating the dune morphologies present in abyssal dunefields, including A: a giant transverse dunes south of Sri Lanka: $1^{\circ} 13^{\prime} 26.19^{\prime} \mathrm{S}, 80^{\circ} 15^{\prime} 29.18^{\prime} \mathrm{E}$. This transverse dunefield contains the largest abyssal dunes located so far with wavelengths of $8-10 \mathrm{~km}$ and heights up to 347 meters, possibly making these the largest bedforms on Earth. C: Large linear dunes Northeast of Papua. $2^{\circ} 4^{\prime} 20.99^{\prime} N, 147^{\circ}$

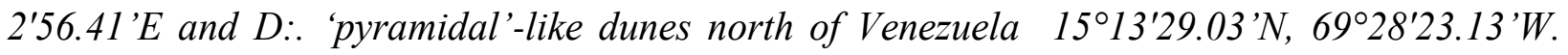
These fields are defined on the map (Fig. 5C) as areas of deposition on the ocean floor. 


\section{Contourite depositional systems}

Like the Gulf of Cadiz Mediterranean Outflow Water system shown previously, several other large scale contourite depositional systems can be recognized from their planform distribution and are visualized through the results of this study. For example, moat and drift systems are a type of contourite system that can develop in sub-abyssal ( $<1,000$ meters) water depths (Faugères et al., 1999). These systems are fed with sediment from continents, which are separated into a coarse component that is deposited in a moat. In these moats, fine material is winnowed, which defines it as an erosional zone on the bottom current erosion map. Secondly, these system also have a fine 'drift' component, which is carried further basinward by geostrophic or deep tidal currents (Miramontes et al., 2020). Such systems are visible on the map as elongate erosional zones surrounded by relatively extensive depositional areas (Figs. 10; 11).

Plastered drifts are depositional areas that collect fine grained sediment from the water column and deposit them on continental slopes, where shear stresses are relatively high. Such areas are visible on the map as extensive (up to hundreds-of-km long) patches of deposition (Fig. 11). Other types of contourites like mounded, separated or elongate drifts can be distinguished based on their setting and shape and are all visible as depositional system on the map simulations.

The map also shows regions containing extensive abyssal dunefields, which are the most extensive deep marine depositional systems and are geomorphologically similar to terrestrial ergs or 'sand seas' (Figs. 8; 12). Abyssal dunefields contain a wide variety of dune types and sizes of various morphologies such as barchan (Carnegie Ridge; Lonsdale and Spiess, 1977; Lonsdale and Malfait, 1974), transverse (e.g. Zapiola drift) or linear (e.g. Feni drift) dunes. In contrast to aeolian systems these 'deserts of the deep' are comprised of fine grained muds and clays and are sculpted over extremely long timescales by continuous bottom currents (Lonsdale and Malfait, 1974). 


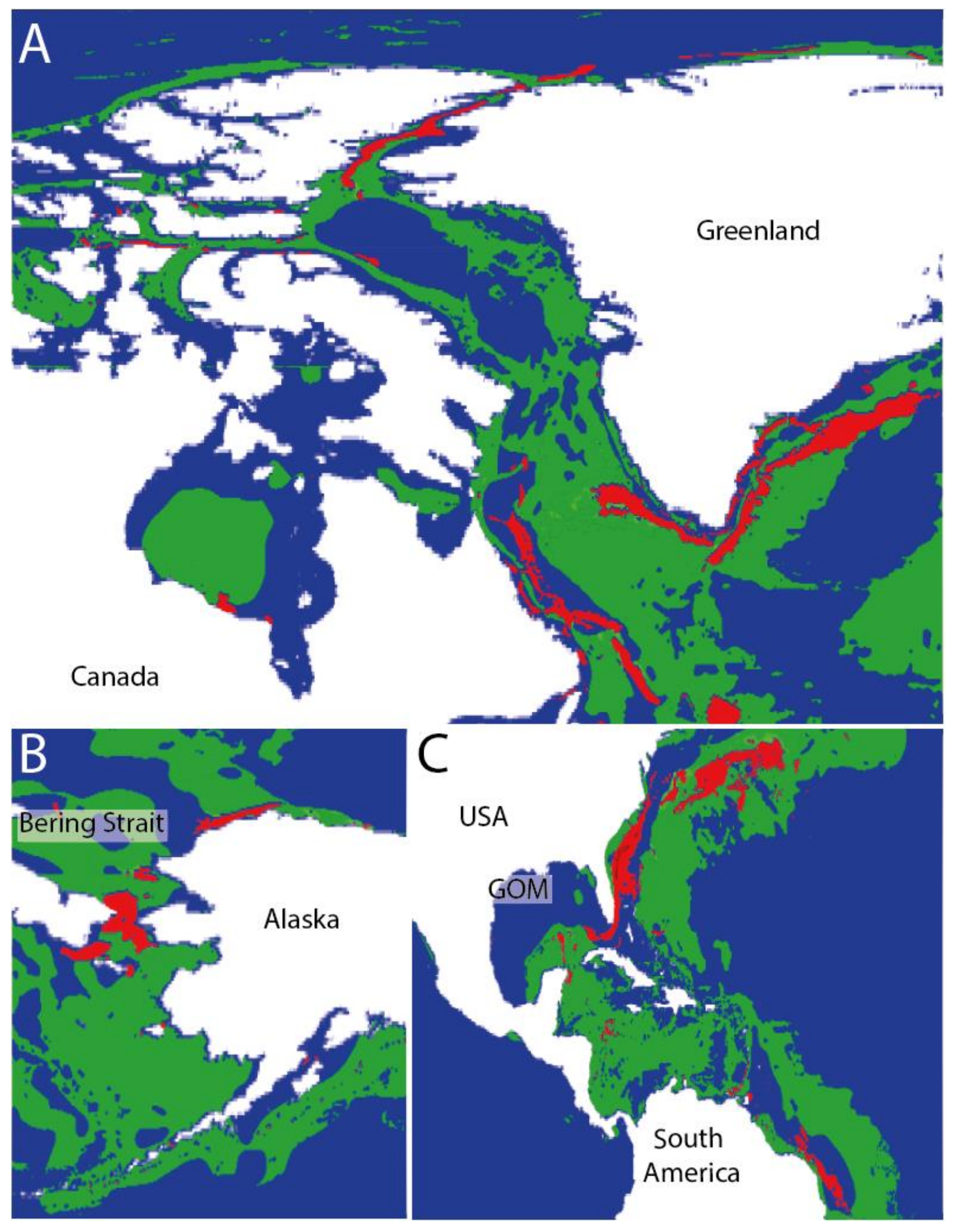


Figure 10. Depositional and erosional bottom current systems around North America. A.) Elongate moat (red) and drift (green) systems formed by movement of boundary currents around Greenland. Narrow sea straits in between the Nanavut Islands generate erosion. B: The Bering Strait, located between the land masses of Alaska and Russia has amplified tidal currents which generate erosion toward the center of the Strait and deposition at the strait's north and south entrances. C: Intense Gulf Stream Boundary currents occur off the East Coast of the United States and generate extensive zones of erosion at the shelf margin toe of slope, and around the carbonate margins of south Florida. Deposition occurs on the eastern shelf where terrestrial sediments feed the formation of seafloor constructs. See figure 5C for color legend.
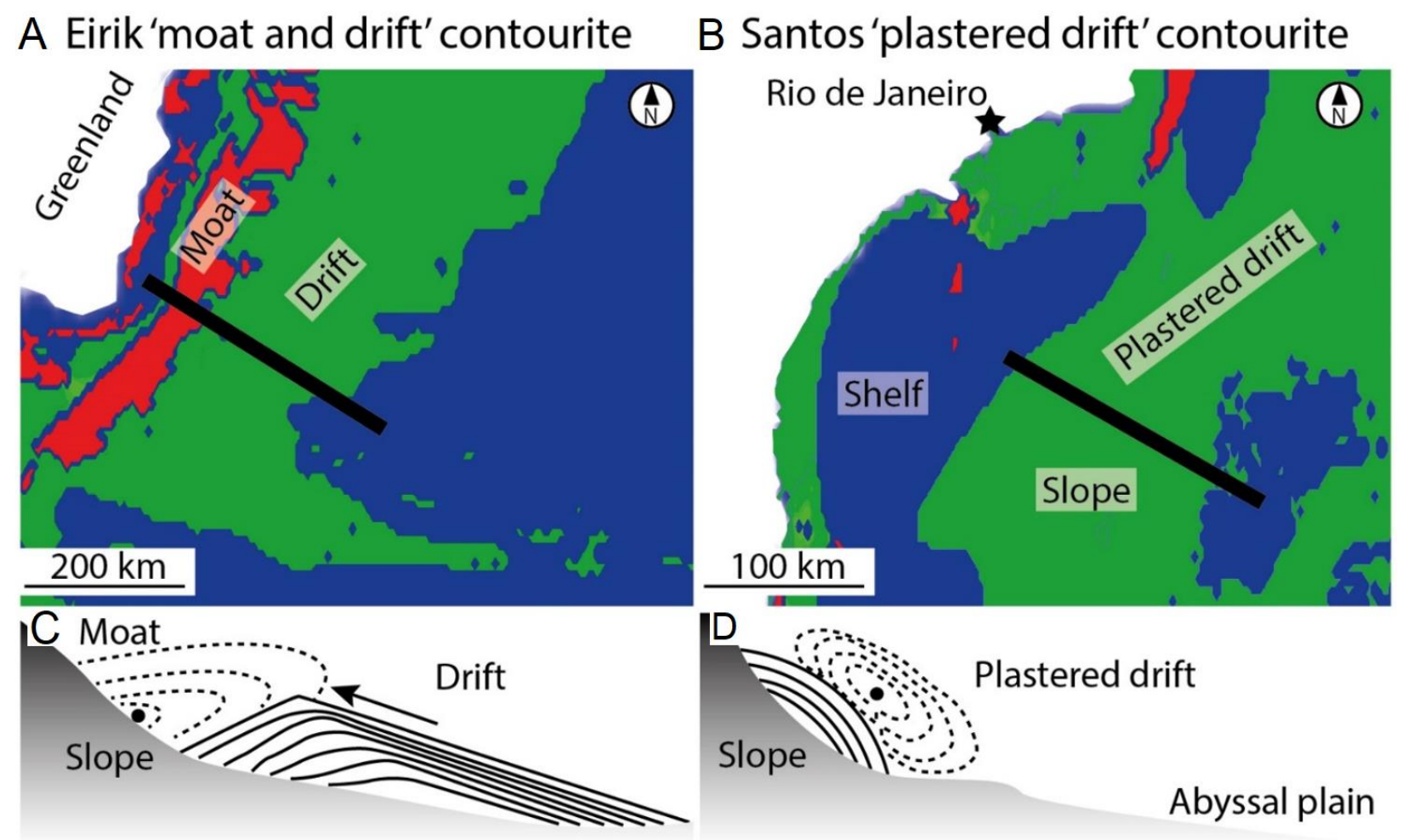

Abyssal plain

Figure 11. Comparison between model results and schematic, cross-sectional models that represent the plan form geometries. Cross-sectional models are developed from seismic data by Faugères et al. (1999). Figure shows a map view of a moat and drift deposit, located, southeast of Greenland (Eirik drift), and a map view of a plastered drift deposit located off the coast of Uruguay. 


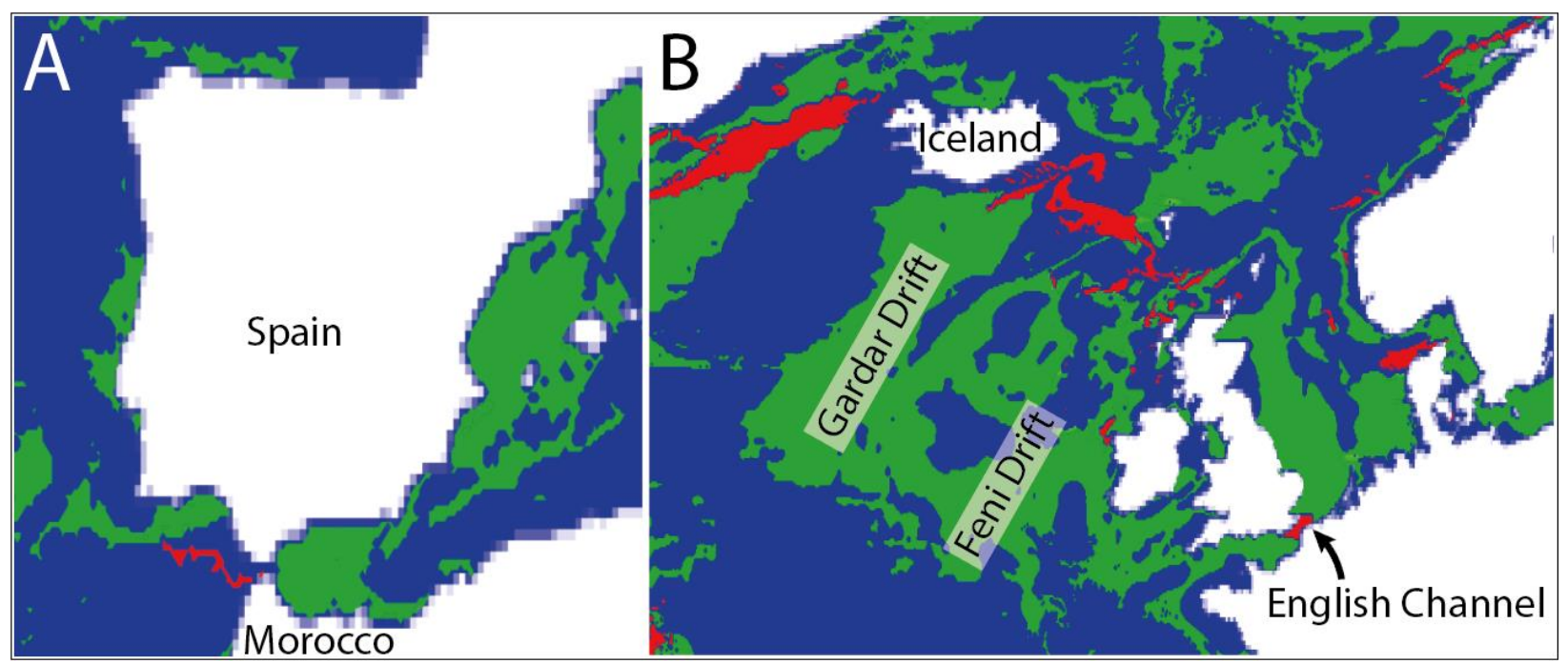

Figure 12. Depositional and erosional bottom current systems around Western Europe. A. contourites are deposited south of Spain where Mediterranean Outflow Water moving between Spain and Morocco erodes and deposits sediments on the seafloor. B. The North Atlantic is a major zone of bottom current deposition. Several large drifts sit adjacent one another (i.e.., Feni Drift, Gardar Drift). Erosion is occurring in areas between adjacent continents (i.e.. English Channel, Öresund) in areas near the base of the continental slope east of Nova Scotia, or across the area of the North Sea between Iceland and the United Kingdom. See figure 4C for color legend.

\section{Sediment types}

We recognize that a major caveat on estimating boundary values for erosional and depositional shear stresses is the lack of input on grainsize and sediment type distribution on the ocean floor. Sea floor sediment type maps have been published for example in Dutkiewicz et al. (2015), but these remain somewhat troublesome, as they give little information on grainsizes. This lack of important data is a major weakness of this work, but since the model presented in this study is empirical and derived from direct observations of seafloor morphologies, the map developed herein can be helpful for broadly predicting the dispersal of thermohaline-driven geostrophic bottom current deposits, as well as zones of erosion. Future work can therefore expand on this study by populating the models presented herein with local information on sediment grainsizes.

\section{Deep marine resources}

Mineral resources on the abyssal plain are abundant, and a potential future target for economic extraction (Antrim, 2005). The bottom current deposition and erosion map present here can give insights into zones of seafloor erosion processes that can locally enrich the abyssal plain in mineral resources such as ferromanganese nodules. For example erosional regions can experience deflation of the sediments that surround much heavier nodules, thereby concentrating potentially valuable nodules and concretions (Lonsdale and Malfait, 1974). Furthermore, geostrophic currents have 
been shown to strongly impact the properties of sedimentary rocks on the ocean floor by eroding and transporting sandy sediments to adjacent depocenters, or alternatively by concentrating sandy sediments in specific sediment dunefields. The homogeneous and extensive nature of these dunefields creates the opportunity for spatially extensive hydrocarbon reservoir development in ultra-deep waters, beyond the margins of clastic submarine fans, thus extending opportunity to deeper and deeper settings. Finally, understanding the variables that control the dispersal of sediments in deep ocean regions can lead to predicting the occurrence of these reservoirs in older ocean systems, as well as better understanding ancient regimes of bottom current circulation.

\section{CONCLUSIONS}

In this study three types of data are integrated: 1) high-resolution bathymetry data to visualize erosional and depositional features on the ocean floor 2), models of bottom shear stress from the HYCOM numerical ocean model. 3) Models of sediment thickness from the GlobSed ocean sediment thickness map. Using these three types of data, regimes of ocean bottom-current deposition, erosion and stasis (neither deposition nor erosion), are identified and extrapolated across the ocean floor. This allows for mapping of the dispersal of contourites, abyssal dunefields and erosional systems in shelf, slope and abyssal regions of the world's oceans. The completed map is cross-referenced with existing maps that show the dispersal of contourites and abyssal dunefields is accurately tracked across the world using this methodology. The bottom current deposition and erosion map is also used to illustrate various types of contourite depositional systems and develop a series of generalized patterns that govern the dispersal of depositional and erosional bottom current systems in the world's oceans. Areas with high bottom current deposition are: continental slopes affected by boundary currents, barotropic vortices, submarine mounds, platforms and other obstructions on the seafloor. Areas of erosion: confined areas like sea straits and continental slopes affected by strong erosional boundary currents. Areas of stasis: Zones of deep water upwelling, zones of deepwater formation, mid-ocean ridges, some continental shelves, enclosed basins and seas. Future improvements to this study can be made by populating the data presented here, with models of various ocean floor lithologies and grainsizes.

\section{REFERENCES}

Antrim, C. L. (2005). What was old is new again: Economic potential of deep ocean minerals the second time around. In Proceedings of OCEANS 2005 MTS/IEEE (pp. 1311-1318). IEEE.

Beelen, D., Wood, L. J., Zaghloul, M. N., Arts, M., and Sarg, F. (2021). Shallow or deep? A reinterpretation of the Rifian Corridor's unique sandy contourites.

Breitzke, M., Wiles, E., Krocker, R., Watkeys, M. K., and Jokat, W. (2017). Seafloor morphology in the Mozambique Channel: evidence for long-term persistent bottom-current flow and deepreaching eddy activity. Marine Geophysical Research, 38(3), 241-269. 
Chassignet, E. P., Hurlburt, H. E., Smedstad, O. M., Halliwell, G. R., Hogan, P. J., Wallcraft, A. J., ... and Bleck, R. (2007). The HYCOM (hybrid coordinate ocean model) data assimilative system. Journal of Marine Systems, 65(1-4), 60-83.

Chelton, D. B., \& Schlax, M. G. (1996). Global observations of oceanic Rossby waves. Science, 272(5259), 234-238.

Cheng, L., Trenberth, K. E., Gruber, N., Abraham, J. P., Fasullo, J. T., Li, G., ... \& Zhu, J. (2020). Improved estimates of changes in upper ocean salinity and the hydrological cycle. Journal of Climate, 33(23), 10357-10381.

Claus, S., De Hauwere, N., Vanhoorne, B., Hernandez, F., Mees, J., 2017. MarineRegions.org [WWW document]. URL MarineRegions.org. (Accessed 15 September 2017).

Davis Jr, R. A., and Dalrymple, R. W. (Eds.)., 2011. Principles of tidal sedimentology. Springer Science and Business Media.

Dutkiewicz, A., Müller, R. D., O’Callaghan, S., \& Jónasson, H. (2015). Census of seafloor sediments in the world's ocean. Geology, 43(9), 795-798.

Duarte, C. S., \& Viana, A. R. (2007). Santos Drift System: stratigraphic organization and implications for late Cenozoic palaeocirculation in the Santos Basin, SW Atlantic Ocean. Geological Society, London, Special Publications, 276(1), 171-198.

Flood, R. D., and Shor, A. N. (1988). Mud waves in the Argentine Basin and their relationship to regional bottom circulation patterns. Deep Sea Research Part A. Oceanographic Research Papers, 35(6), 943-971.

Faugères, J. C., and Mulder, T. (2011). Contour currents and contourite drifts. In Developments in Sedimentology (Vol. 63, pp. 149-214). Elsevier.

Faugères, J. C., Stow, D. A., Imbert, P., and Viana, A. (1999). Seismic features diagnostic of contourite drifts. Marine Geology, 162(1), 1-38.

Flood, R. D., Shor, A. N., and Manley, P. L. (1993). Morphology of abyssal mudwaves at Project MUDWAVES sites in the Argentine Basin. Deep Sea Research Part II: Topical Studies in Oceanography, 40(4-5), 859-888.

Flood, R. D., Hollister, C. D., and Lonsdale, P. (1979). Disruption of the Feni sediment drift by debris flows from Rockall Bank. Marine Geology, 32(3-4), 311-334.

Flood, R. D. (1981). Distribution, morphology, and origin of sedimentary furrows in cohesive sediments, Southampton Water. Sedimentology, 28(4), 511-529. 
Garrett, C., \& Munk, W. (1979). Internal waves in the ocean. Annual review of fluid mechanics, 11(1), 339-369.

Heezen, B. C., and Hollister, C. D. (1971). Face of the deep.

Heezen, B. C. (1959). Dynamic processes of abyssal sedimentation: erosion, transportation, and redeposition on the deep-sea floor. Geophysical Journal International, 2(2), 142-163.

Hüneke, H., and Stow, D. A. V. (2008). Identification of ancient contourites: problems and palaeoceanographic significance. Developments in Sedimentology, 60, 323-344.

Hernández-Molina, F. J., Sierro, F. J., Llave, E., Roque, C., Stow, D. A. V., Williams, T., ... and Brackenridge, R. E. (2016). Evolution of the gulf of Cadiz margin and southwest Portugal contourite depositional system: Tectonic, sedimentary and paleoceanographic implications from IODP expedition 339. Marine Geology, 377, 7-39.

Hollister, C. D., and Heezen, B. C. (1972). Geologic effects of ocean bottom currents: western North Atlantic.

Jacox, M. G., Edwards, C. A., Hazen, E. L., and Bograd, S. J. (2018). Coastal upwelling revisited: Ekman, Bakun, and improved upwelling indices for the US West Coast. Journal of Geophysical Research: Oceans, 123(10), 7332-7350.

Klaus, A., and Ledbetter, M. T. (1988). Deep-sea sedimentary processes in the Argentine Basin revealed by high-resolution seismic records (3.5 kHz echograms). Deep Sea Research Part A. Oceanographic Research Papers, 35(6), 899-917.

Lonsdale, P., \& Malfait, B. (1974). Abyssal dunes of foraminiferal sand on the Carnegie Ridge. Geological Society of America Bulletin, 85(11), 1697-1712.

Lonsdale, P., \& Spiess, F. N. (1977). Abyssal bedforms explored with a deeply towed instrument package. In Developments in Sedimentology (Vol. 23, pp. 57-75). Elsevier.

Locker, S. D., and Laine, E. P. (1992). Paleogene-Neogene depositional history of the middle US Atlantic continental rise: mixed turbidite and contourite depositional systems. Marine Geology, 103(1-3), 137-164.

Marks, K. M., and Smith, W. H. F. (2006). An evaluation of publicly available global bathymetry grids. Marine Geophysical Researches, 27(1), 19-34.

Masson, D. G., Howe, J. A., and Stoker, M. S. (2002). Bottom-current sediment waves, sediment drifts and contourites in the northern Rockall Trough. Marine Geology, 192(1-3), 215-237. 
Miramontes, E., Eggenhuisen, J. T., Jacinto, R. S., Poneti, G., Pohl, F., Normandeau, A., and Hernández-Molina, F. J. (2020). Channel-levee evolution in combined contour current-turbidity current flows from flume-tank experiments. Geology, 48(4), 353-357.

McCave, I. N., and Tucholke, B. E. (1986). Deep current-controlled sedimentation in the western North Atlantic.

Mulder, T., Syvitski, J. P., Migeon, S., Faugeres, J. C., and Savoye, B. (2003). Marine hyperpycnal flows: initiation, behavior and related deposits. A review. Marine and Petroleum Geology, 20(68), 861-882.

Niedoroda, A. W., Reed, C. W., Hatchett, L., Jeanjean, P., Driver, D., Briaud, J. L., and Bryant, W. (2003, January). Bottom currents, deep sea furrows, erosion rates, and dating slope failureinduced debris flows along the Sigsbee escarpment in the deep Gulf of Mexico. In Offshore Technology Conference. Offshore Technology Conference.

Principaud, M., Mulder, T., Hanquiez, V., Ducassou, E., Eberli, G. P., Chabaud, L., and Borgomano, J. (2018). Recent morphology and sedimentary processes along the western slope of Great Bahama Bank (Bahamas). Sedimentology, 65(6), 2088-2116.

Rebesco, M., Camerlenghi, A., and Van Loon, A. J. (2008). Contourite research: a field in full development. Developments in sedimentology, 60, 1-10.

Rebesco, M., and Stow, D. (2001). Seismic expression of contourites and related deposits: a preface. Marine Geophysical Researches, 22(5), 303-308.

Rebesco, M., Hernández-Molina, F. J., Van Rooij, D., and Wåhlin, A. (2014). Contourites and associated sediments controlled by deep-water circulation processes: State-of-the-art and future considerations. Marine Geology, 352, 111-154.

Rich, J. L. (1951). Three critical environments of deposition, and criteria for recognition of rocks deposited in each of them. Geological Society of America Bulletin, 62(1), 1-20.

Saunders, P. M., \& King, B. A. (1995). Bottom currents derived from a shipborne ADCP on WOCE cruise A11 in the South Atlantic. Journal of Physical Oceanography, 25(3), 329-347.

Spall, M. A. (1996). Dynamics of the Gulf Stream/deep western boundary current crossover. Part II: Low-frequency internal oscillations. Journal of Physical Oceanography, 26(10), 2169-2182.

Stow, D. A., Hernández-Molina, F. J., Llave, E., Sayago-Gil, M., Díaz del Río, V., \& Branson, A. (2009). Bedform-velocity matrix: the estimation of bottom current velocity from bedform observations. Geology, 37(4), 327-330.

Stow, D. A., Faugères, J. C., Viana, A., and Gonthier, E. (1998). Fossil contourites: a critical review. Sedimentary Geology, 115(1-4), 3-31. 
Stow, D., Smillie, Z., and Esentia, I. P. (2018). Deep-Sea bottom currents: Their nature and distribution. In Encyclopedia of ocean sciences: earth systems and environmental sciences.

Stow, D. A. V., and Lovell, J. P. B. (1979). Contourites: their recognition in modern and ancient sediments. Earth-Science Reviews, 14(3), 251-291.

Straume, E. O., Gaina, C., Medvedev, S., Hochmuth, K., Gohl, K., Whittaker, J. M., ... and Hopper, J. R. (2019). GlobSed: Updated total sediment thickness in the world's oceans. Geochemistry, Geophysics, Geosystems, 20(4), 1756-1772.

Toucanne, S., Mulder, T., Schönfeld, J., Hanquiez, V., Gonthier, E., Duprat, J., ... \& Zaragosi, S. (2007). Contourites of the Gulf of Cadiz: a high-resolution record of the paleocirculation of the Mediterranean outflow water during the last 50,000 years. Palaeogeography, Palaeoclimatology, Palaeoecology, 246(2-4), 354-366.

Trossman, D. S., Arbic, B. K., Richman, J. G., Garner, S. T., Jayne, S. R., and Wallcraft, A. J. (2016). Impact of topographic internal lee wave drag on an eddying global ocean model. Ocean Modelling, 97, 109-128.

Thran, A. C., Dutkiewicz, A., Spence, P., and Müller, R. D. (2018). Controls on the global distribution of contourite drifts: Insights from an eddy-resolving ocean model. Earth and Planetary Science Letters, 489, 228-240.

Volkov, D. L., and Fu, L. L. (2008). The role of vorticity fluxes in the dynamics of the Zapiola Anticyclone. Journal of Geophysical Research: Oceans, 113(C11).

Viana, A. R., Faugères, J. C., and Stow, D. A. V. (1998). Bottom-current-controlled sand deposits - a review of modern shallow-to deep-water environments. Sedimentary Geology, 115(14), 53-80.

Xie, L., and Hsieh, W. W. (1995). The global distribution of wind-induced upwelling. Fisheries Oceanography, 4(1), 52-67.

Zenk, W. (2008). Temperature fluctuations and current shear in Antarctic Bottom Water at the Vema Sill. Progress in Oceanography, 77(4), 276-284.

\section{DATA AVAILABILITY STATEMENT}

All data generated or analyzed during this study are included in this published article (and its supplementary information files).

\section{FUNDING STATEMENT}

Funding was provided through the SAnD Consortium. Additional funding was provided by the Bartshe endowment. 